\title{
The Process of Brexit and Possible Models for EU \& UK's Future
}

\author{
Brexit Süreci ve AB ile Ingiltere'nin Geleceği Iç̧in Olası Modeller
}

\section{Yakup BULUT}

Prof. Dr., Hatay Mustafa Kemal Üniversitesi, IIBF, Siyaset Bilimi ve Kamu Yönetimi Bölümü, ybulut@mku.edu.tr https://orcid.org/0000-0002-0838-4200

\section{Soner AKIN}

Dr. Öğr. Üyesi, Hatay Mustafa Kemal Üniversitesi, İBF, Siyaset Bilimi ve Kamu Yönetimi Bölümü, sakin@mku.edu.tr https://orcid.org/0000-0002-2403-8041
Makale Başvuru Tarihi: 08.11.2019

Makale Kabul Tarihi: 27.12.2019

Makale Türü: Araştırma Makalesi

\section{Anahtar \\ Kelimeler:}

Brexit,

Ingiltere ve $A B$,

$A B^{\prime}$ den Sonra

\section{ÖZET}

Brexit veya Brexit krizi, Avrupa Birliği'nden İngiltere çıkışına başlayan sürece verilen (Avrupa Birliği'nden Ingiltere'nin çıkışının kısa kod adı olarak) isimdir. Bilindiği gibi, bu süreç, AB'yi \% 52 oranına yakın değerde birakmak isteyen destekçilerin 23 Haziran 2016'daki referandumun ardindan zaferiyle resmiyet kazanmıştır. Günümüzde, mevcut süreç farklı bir anlam daha kazanmıştır, bu nedenle bugün, 29 Mart 2017'de başlayan ayrılık müzakerelerini erteleme anlaşmalarının gerçekleştirilmesine de atıfta bulunmaktadır. Ingiltere'de Avam Kamarası 14 Ekim'de 2019'da, iktidardaki Muhafazakar Partinin ilıml Muhafazakar Milletvekili Oliver Letwin tarafindan önerilen değişikliğin kabul edilmesi üzerine gecikmeli olarak harekete geçebilmiştir. Letwin'in değişiklik önerisi, Brexit anlaşması yürürlüğe girmeden önce Ingiltere'nin ihiç antlaşma yapmadan AB'yi terk etmesini engellemeyi hedeflemiştir. Bu çalışmada, Brexit'in olası süreci ele alınacak ve İngiltere'nin beklenen yeni dış politikası ve mevcut AB üyesi ve aday ülkeleri üzerindeki etkileri farkl modeler üzerinden incelenektir.

\section{ABSTRACT}

The Brexit or Brexit crisis is the same term for the UK exit beginner project of the European Union (known as the code name for the meaning as British exit from the European Union). As is known, this process was started officially started via following the referendum of 23th June in 2016 which presented the victory of the supporters who had been wishing to leave the EU at the near value as \%52. Nowadays, the exist process gained a different meaning, hence it refers today to realizing the withdrawal agreements negotiated with the long withdrawal procedure started on $29^{\text {th }}$ March in 2017. The new Brexit agreement was scheduled to be voted as a motion at the extraordinary session of the House of Commons on $14^{\text {TH }}$ October in 2019, but upon the adoption of the proposed amendment by Oliver Letwin, the moderate Conservative MP of the ruling Conservative Party, the government withdrew the motion. Letwin's amendment proposal aims to prevent Britain from "accidentally" leaving the EU unintentionally before the Brexit agreement is enacted. In this paper the possible process of Brexit will be discussed, and its effects on UK's foreign policy and available EU member and candidate countries are going to be paid attention. 


\section{INTRODUCTION}

In November 2018, the negotiations between Theresa May's government and the EU represented by Michel Barnier lead to a draft agreement to withdraw the United Kingdom from the European Union, but it is rejected three times, in January and March 2019 by the British Parliament, resulting in a political blockage (Fabbrini, 2019: 15). In order to avoid March 29, 2019 an exit without agreement, considered to be dangerous, Theresa May and the Commission agree to an extension to 12 April 2019 if the agreement is not adopted the first week of April, and to 22 May 2019 if the agreement is adopted on that date. However, in view of the persistence of the political blockage in the United Kingdom and the adoption of the Cooper-Letwin law on 8 April 2019, the British Parliament takes control over the duration of extension requests that the government can make to the European Council, which could result in a long extension request (Frosini, 2019). The United Kingdom's exit from the European Union, known as Brexit, is a controversial political project that is being prepared for the EU membership referendum in the United Kingdom on 23 June 2016. In the referendum, 51.89 percent of the participants voted in favor of the United Kingdom leaving the European Union (Arnorsson and Zoega, 2018: 305). As a result, the Brexit referendum held in the United Kingdom in 2016 was decided to leave the EU with 52 percent against 48 percent. However, 46 per cent of the voters in the UK, 47 per cent in Wales, 56 per cent in Northern Ireland, and 62 per cent in Scotland voted for the continuation of EU membership (Blick, 2018: 133). Since 29 March 2017, no concrete agreement on the withdrawal date had been, made; this would have come to the end of the two-year negotiations on 29 March 2019. The withdrawal date has since been postponed three times, most recently on 31 January at the latest date for the year as 2020.

Figure 1: Map of Brexit votes' characteristics on being Eurosceptic

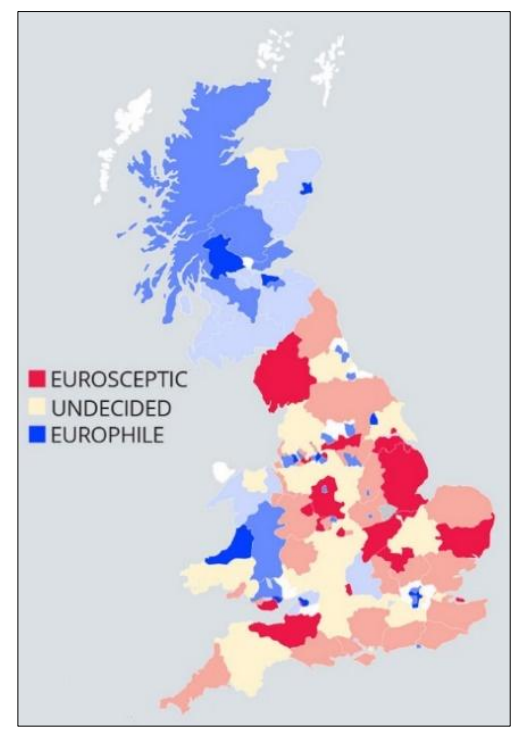

Resource: Express, 2016

According to forecasts, Brexit will hit the United Kingdom in particular economically, indeed, this has to be discussed in the context of an unregulated exit's results for an international frame too. It is also expected that the withdrawal of the UK net contributor will also have a significant impact on the EU, with Germany and other more intertwined countries in the Union also forecasting economic losses. United Kingdom, Turkey with his departure from the European Union, Iran, India, China, Saudi Arabia, Kuwait, Qatar, Russia, the United States, Canada, Australia, New Zealand and the trade negotiated as Japan and the European Union's export back with 52 countries in the area of trade aims to increase (Stansfield et. al, 2018: 235). The European Union said that if the United Kingdom leaves the European Union, the United Kingdom should make these agreements by itself. There are three models in the minds of those who want the UK to leave the European Union. 
Figure 2: Map of Brexit votes' distribution

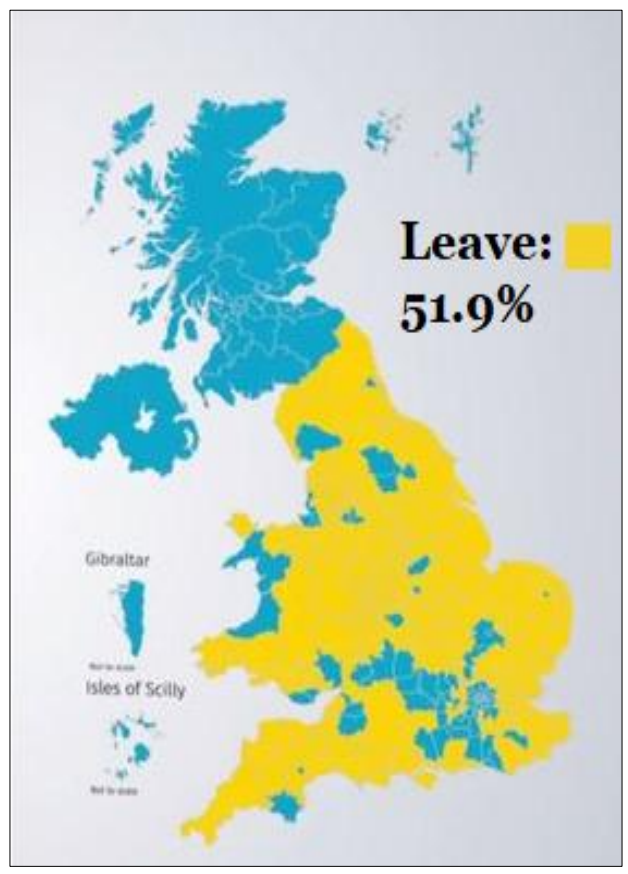

Resource: Huffingtonpost, 2016

\subsection{A Norwegian Model: UK on Joining European Economic Area}

This model will be an adaptation of a model which belonged to Norway. In this mode, the United Kingdom may join the European Economic Area (EEA), such as Norway, and can continue to trade from there (Fossum and Graver, 2018). Norway is a member of the European Free Trade Association, together with Switzerland, Iceland and Liechtenstein. The European Economic Area, shortly known as EEA, was established by a series of agreements signed between the three members of EFTA, with the exception of Switzerland, and the European Union (Schewe and Lipsens, 2018:223). Norway has therefore become part of the same economic sphere as the European Union. Now in this area, again as a discrete member like Norway, UK can take place. The European Economic Area has given Norway a chance to enter the European Internal Market. In other words, it has given the opportunity to benefit from four fundamental freedoms on the circulation of goods, persons, capital and services. Naturally, Norway is obliged to apply the European acquis regulating the Internal Market at many levels (Duff, 2018). The Norwegian model was previously undesirable for the United Kingdom. Indeed, even though the United Kingdom saw the free movement of goods, capital and services as in its interests, it never wanted the free movement of persons. One of the main reasons behind the Brexit decision is the free movement of persons. Therefore, if the United Kingdom takes part in a model in which people accept free movement after the Brexit, then the Brexit decision will lose its meaning and the people will again contradict with the government. This model is no longer attractive or possible for the European Union. This is because the European Union has been complaining that Norway, which is not a member of the European Union, has had difficulty in adopting and implementing the European acquis. Adding the United Kingdom to the list of complaining countries does not seem to be a possible and satisfying model for the European Union (Grynberg et. al, 2019).

Whether or not Norway joins the EU is one of the most polarizing subjects in Norwegian politics since the Second World War, thus a similar fate would wait for UK, if she accepted this model. EU legislation relevant to the EEA is incorporated into the agreement of 1994 and transposed into national laws (Vahl and Grolimund, 2006). The EEA agreement includes cooperation in areas such as research and development, education, social policy, environment, consumer protection, business, tourism and culture. However, the common agricultural policy and fisheries policies, the customs union, the common commercial policy, the economic and monetary union, the common foreign and security policy, and the issues of justice and home affairs (although EFTA countries are part of the Schengen Area). Therefore, the laws in relation to the European market are also applicable in Norway. Since 2009, Norway has decided to participate in EU projects and its total financial contribution related to the EEA agreement consists of contributions related to participation in these projects 
which are FRONTEX, Schengen Agreement, EU Drug Monitoring Center, the European Defense Agency, Europol, etc., and part distributed for development projects to reduce social and economic disparities in the European Union (Carrera et.al, 2016). Differently from UK, Norway's conservative block supports the membership. Again Labor Party of Norway can be seen other supporter. Indeed, the most powerful block as Liberal Party give us the separated view in its division on supporting membership, so the membership debates are seen out of concern in current debates after 2009 (Budge and Laver, 2016). What complicates the issue has been that a wide variety of political and emotional factors have been raised in the debate. Radical socialists oppose membership due to opposition to conservative economic and political forces that concern them within Europe; opponents to the right are worried about a violation of Norwegian culture; and others oppose in principle to compromise Norwegian sovereignty (Bale, 2003: 72). Of course, these political motives are far away from a country, which had already experienced the status on being a member, as UK had done. Currently, parties that support or oppose accession to the European Union can find themselves in coalitions of both right and left: as a result, most governments contain pro and anti-EU elements. Indeed, discussing a new debate on joining EU can resolve the coalition forces, thus most of the political institutions even the Europeanists want to avoid from it.

Norway, as a response for its own participation in the European single market, made a significant contribution to EU cohesion. Indeed, in Norway, two financial mechanisms have been set up, i.e. the EEA Financial Mechanism, of which donors were Norway, Iceland, Liechtenstein, and, the other one as a Norwegian Financial Mechanism. For the period 2009-2014, the EEA and Norwegian Financial Mechanisms provide for payments totaling 1.8 billion euro under this roof (Lytvynchenko, 2016: 201). This also represented an increase of 22\% over the previous five-year cycle. Norway also contributed them with a ratio as $97 \%$. The agreement was signed at the end of July 2010. The period after this year was critical as the biggest expansion of Union realized. As is well known, the beneficiary countries were the countries which joined the EU in 2004 and 2007, in addition to these countries in need as Portugal, Greece and Spain. In other words, UK can also face an issue in the future on giving financial aids, on behalf of being a market partner. The unemployment rate fell and purchasing power increased significantly in Norway after this partnership and UK can also investigate new ways to catch the same results with being only a partner in a common market like Norway. Norway's economy benefited from the export of oil and gas as well as fish and seafood to the EU member states, but an already member country as UK find other ways to gain benefits. Today, $45 \%$ of all UK exports is derived from UK-EU trade and 53\% of all UK imports are coming from EU. Both of them are falling, looking at the past approximate 20 years. In this respect being the most active outsider for the Union might be changed in a model, when UK's possible choice on adapting Norway format is realized (Ward, 2019)

\subsection{Switzerland Model: Being a European Economic Commission Member, and Concluding The Trade Agreements By Herself}

The relations between Switzerland and the European Union, despite ancient, have been reinforced after the rejection by the Swiss people to ratify the agreement on the European Economic Area by referendum on December 6, 1992. Indeed, relations have been renegotiated through agreements and bilateral documents that have avoided the risk of isolation due to the refusal to ratify the EEA. The result of the referendum in 1992 revealed a country divided into the question. Taking advantage of the situation, the extreme right of Switzerland, specifically the Lega group (Lega dei Ticinesi), known as League of Ticinesians, and Demócrates party, proposed another referendum where citizens were asked if they wanted to freeze and block all kinds of discussion with the European Union (Kessel, 2015:43). The extreme right demanded then abandons the negotiations on the accession of the country. The result puts aside the petitions of the extreme right that $73.9 \%$ rejected the will to freeze relations with the EU. In spite of the rejection of 1992 and the demands of the extreme right, the truth is that in Switzerland several different political groups have succeeded in the European Union, quite dispersed. It is not until 1998 that they manage to group under the acronyms of NOMS, which is known as New Swiss European Movement (Euobserver, 2016). Along with the extension of the members of the European Union, Switzerland has held referendums on whether the entry of new countries in the area of free movement was accepted. In all the results, they have been favorable to the point of approving Switzerland's contribution to European sources of aid for cohesion; especially for the newly arrived countries of the East Europe. But immigration and the challenges it posed - seeing the European extension - make the nationalist and conservative UDC (Democratic Union of the Center) achieve that the Swiss accept in 2014 to stop "mass immigration" with a high participation and a 56, 5\% favorable votes. The EU doesn't waste time on reprisals and exempts Swiss from Erasmus programs. This requires the Federal Council to find an urgent solution to free movement with 
Croatia. In 2016, Switzerland definitively withdraws the application form for membership in the European Union. After the referendum in Switzerland, which ended in favor of restricting immigration from the EU, it reviews relations with the European Union. In March 2016, the National Council also voted in favor of a motion by National Councilor Lukas Reimann in mid-June 2016, asking the government to withdraw the petition. Indeed, Federal Councilor Didier Burkhalter confirmed that they would inform the EU that the application had to be considered completed (Snbchf, 2016).

The adaptation of the Swiss model for the United Kingdom is also unlikely in many ways. Because until the immigration crisis in Switzerland the tendency to become a member of the EU was on the agenda. Nowadays, the development of a strategy in support of the Switzerland with the United Kingdom has raised these discussions. In February of 2019, Switzerland and England are preparing for the aftermath of Brexit. Swiss Economy Minister Guy Pamelin and UK International Trade Minister Liam Fox came together in Bern, Switzerland and signed a free trade agreement which will take effect after Britain leaves the European Union (Guardian, 2019).The Swiss model, which is based on hundreds of agreements, is another model, but it is difficult to imagine that this agreement would be an option for England considering that it does not even satisfy Switzerland. A Free Trade Agreement with the EU, or a privileged status, like the Customs Union model between Turkey and the EU stands like having a stronger possibility among the other options. The regulation, adopted by a small margin in referendum, foresees a significant restriction on the number of immigrants in Switzerland and foresees the agreement on the free movement of individuals in the European Union within three years. The 1999 Free Movement Agreement established the gradual introduction of the free movement of persons between Switzerland and the EU, as it already applied between the members of the European Union (Van der Mei, 2003). Under certain conditions, the Agreement on the Free Movement of Persons provides for rights of residence for EU citizens and their family members in Switzerland and vice versa. In principle, three different transitional arrangements can be distinguished for the EU-15, EU-8 and for Bulgaria and Romania (Baas and Brücker, 2011:49). During these transitional arrangements, immigration restrictions such as national priority, control of pay and working conditions and quota allocation can be maintained. This type of secretive regime can be perceived as attractive to think about the future of UK and EU in a similar format of motives. When it is compared with Norway model, it can be seen that being a full member as Norway isn't valid for Switzerland model, thus it is partially. The contribution on EU budget, as it was discussed above with financial mechanisms' frame is relatively low, compared with Norway.

\subsection{Hub and Spoke Model: Being a European Economic Commission Member, plus both Concluding the Trade Agreements by Herself and Accepting the Derivative Norms in Her Parliament}

A group of 110 integration-friendly EU parliamentarians from four parties on April $9^{\text {th }}, 2013$, presented a draft for a comprehensive constitution of the EU. The main advantage of the new treaty, according to liberal British parliamentarian Andrew Duff, is that it would create a European government for the fiscal union (Duff, 2016:52). According to him, now, it is about creating the basis "for more solidarity and democracy". According to Duff, the proposed Basic Law is based heavily on the EU's original Community methodology, which had largely been abandoned during the financial crisis in favor of enhanced government cooperation. According to the draft, the EU Commission is to be developed into an EU government, which is elected and responsible by the Council and the Parliament. Andrew Duff says that in this model, new members can continue as associate membership. This categorization for Britain, Norway, Switzerland and Turkey were also be included within different ranks in a principle known as hub and spokes (Duff, 2018). Duff pointed out that this approach is in line with the European Economic Commission's mission to safeguard the European interest as a whole (Duff, 2019). The rotating EU presidency should be abolished. Each Council of Ministers should elect their own president. It will be important for the British to be able to offer financial services in the EU - an essential area for the British economy. Britain can only operate there as before when the kingdom is directly integrated into the EU's internal market. 
Figure 3: Map of Brexit voters' distribution on being a supporter of leaving EU, looking at the intense degree

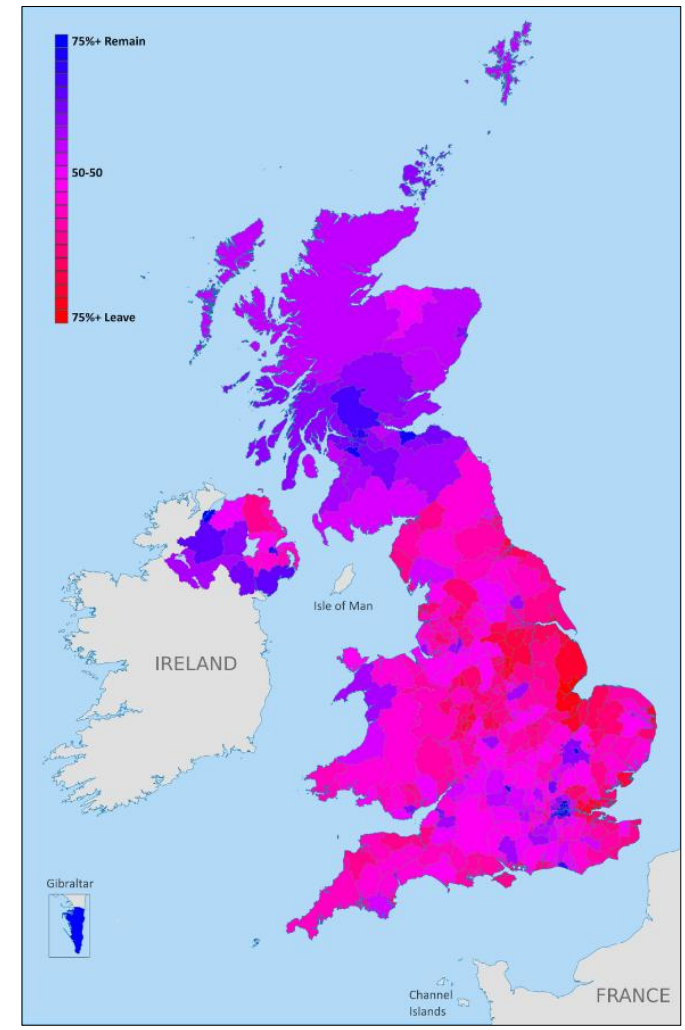

Resource: Political Geography Now, 2016

Duff's opinions are giving a brilliant perspective to understand the future models, recalling the available as well. Andrew Duff is a British politician of the Liberal Democrats. He has been a Member of the European Parliament since 1999 for the constituency of East of England in the United Kingdom of Great Britain and Northern Ireland. Andrew Duff is one of the most prominent representatives of European federalism and was president of the Union of European Federalists. In 2011, he also proposed in a letter to Parliament President Jerzy Buzek that future reforms of the EU Treaty should no longer be unanimous by all Member States, but by a four-fifths majority should be decided (Kucharczyk and Łada, 2017). However, both of these proposals would only be possible by amending the Treaty and would therefore have to be ratified by all EU Member States in accordance with the current legal situation. At this point, Duff found a solution and finally designed a model that could be both a step for the countires which can go out of the EU, and a formula for those countries which want to distance themselves politically from the obligations of full membership, hence it is also a new type of step into the EU, for those types countries which want to obtain full membership status, after all. This associated status would be characterized by close trade relations with the EU. While the Associate Member would lack the say in negotiating EU regulations, observer and consultant status would minimize this deficit. In this way, a multitude of countries would be able to work together as advisory observers with the EU. It would be necessary to determine whether or not there were compulsory consultations with the associated "advisory observers".

\subsection{Other and Similar Scenarios and Future of UK without EU}

The European Commission has reached an agreement with the United Kingdom on a revised protocol on Ireland and Northern Ireland and an agreement on a revised policy statement on future EU-UK relations. The revised protocol provides a legally effective solution that avoids a hard border on the Irish island, protects the island's economy and the Good Friday Agreement, known as Belfast, and ensures the integrity of the EU's single market. Northern Ireland will continue to comply with a number of EU Single Market rules (Doyle and Connolly, 2019:82). The protocol of October $17^{\text {th }}$ will also avoid any customs border on the Irish island while ensuring that Northern Ireland remains part of the UK customs territory. The Northern Ireland Assembly will have a key voice in the long-term application of relevant EU law in Northern Ireland. The most important change in the political declaration concerns future economic relations between the EU and the UK. The Political Declaration reaffirms the objective of concluding a free trade agreement, which excludes tariffs and provides for quotas between the EU and the United Kingdom. 
Anyone who previously wanted to enter the UK from another EU country has already need a valid identity card or passport and have to go through border control. Indeed, the United Kingdom is not a member of the Schengen Agreement, which inter alia regulates the abolition of border controls at internal borders. This will probably not change until the final EU exit. The UK is not a member of the Eurozone and has its own currency, the British pound (Matthijs et. al, 2019: 220). That will probably not change after Brexit. However, Brexit could affect the movement of capital, especially in cash in and out of the UK. So there might be restrictions on cash payments in the future, so-called cash limits. In other words, the rules for registering cash at entry and exit could change. Britain has been divided since the referendum. The trenches run between the regions, between city and country, between rich and poor, between old and young. The negative consequences of a Brexit for the British economy but also for the EU are feared. The EU states have agreed to extend the deadline for Britain to leave the EU by the end of January 2020. In a ratification of the exit agreement, the country could also exit earlier. In the event of an unregulated withdrawal, UK membership in the EU automatically ends, as of the date of departure, the country would be a third country in relation to the EU and the EU acquis would cease to apply to the UK. This would have far-reaching consequences for citizens, the economy and the administration.

The European Union has agreed to extend the UK's departure date (Brexit) to January 31, 2020 at the request of London. Hence, Brexit, which was planned for March 29 ${ }^{\text {th }}, 2019$, was postponed for the third time (Fabbrini, 2019: 14). The 110-page Brexit bill contains the UK's conditions of exit from the EU. The transition period is planned to end on 31 December 2020 if the draft law on leaving the EU passes through parliament. The extension of the transition period will be possible with a secondary legislation. A second referendum, however, will be a possible development if the UK goes to early elections. The payments that the United Kingdom has to make when leaving the European Union appear as if they are paying child support in ordinary divorces. The rights of EU citizens living in the UK after Brexit are still unclear. It is not clear what customs regulations on the border between Northern Ireland and the United Kingdom, which create unrest before joining the Union. It is unclear how EU law in the United Kingdom will be implemented during the transition period after the UK's departure from the EU. It is unclear how the European Court of Justice, like other EU institutions, will act.

After the Second World War, the United Kingdom abandoned its policy of balance of power, that is, the balance of power on the continent, in favor of long-term cooperation with its European neighbors. Since then, the country has had positive ties to the European Union and its members. Points of criticism are the refusal of the United Kingdom to introduce the euro, the agricultural policy of the European Union and, for some countries, its close ties to the United States. Despite centuries of hereditary hostility, France and the United Kingdom have a strong relationship with each other as a result of two world wars in common. Thus, these ties could make France eligible for deepening partnership for economic terms (Compos, 2019). However, there are differing opinions due to the Iraq war and the common agricultural policy. The United Kingdom also shared with the Federal Republic of Germany the need for security vis-à-vis the Soviet Union, resulting in a friendly partnership arising from the Nazi-era relationship. Hundreds of thousands of British soldiers have been stationed on German soil since World War II, and the United Kingdom allowed Germany reunification. A minor burden was the conflicting views on the Iraq war. And this current issue again could make a possible stronger partnership doubtful in future (Saxi, 2019: 141). In general, the EU takes precedence over the Commonwealth for British foreign policy because of its much sharper demarcating interests. In principle, all Commonwealth countries can retain their membership if they choose to become republics as long as they remain democratically aligned. Therefore, partners from Commonwealth roof can be possible for further plans to compensate the gap after EU.

England had continued to support Turkey's EU candidacy, along with Brexit some countries in the EU and Turkey on a support will be reduced. This process may be compensated for by increasing commercial partnerships and prioritization. Following the increase in the influx of refugees to Europe via Turkey it had reached an agreement to limit this trend as the EU and UK parties concerned. The agreement envisions establishing common refugee centers in Europe and restricting the movement of migrants within the union. British cabinet had reached consensus on the draft as if taking any express agreement Brexit place for the citizens of the United Kingdom, Turkey Ankara Agreement allowing the fate of starting a business. The trade volume between England and Turkey have reached \$ 16 billion in 2017 and more than 3 thousand British companies are seen as operating in Turkey in recent years. The volume of trade between countries is also known to have been increased with the rate of one in five. Perhaps these developments in Turkey axis are positive for Turkey, then it could be a new strategic economic partner for UK in the future (Krumm, 2019: 98). 


\section{CONCLUSION}

British Prime Minister Boris Johnson Brexit announced his plan to the public in the House of Commons. Johnson's plan is based on the fact that Northern Ireland remains in the European Common Market, provided it only includes free movement of goods, but leaves the Customs Union. This means that new customs checks are carried out at the Irish border. Thus, it is based on a model that would envisage the creation of a filter-like control mechanism between the UK and Ireland with the Brexit Johnson plan. Ireland will be Britain's economically front yard. When the "secession' campaign from the EU was started by the Conservative political elite with the slogan of economic independence, it was difficult to obtain the support of the economic elite, and the support given to the campaign was in expectation of more jobs, higher salaries and better public services. The resignation of Prime Minister Cameron after a simple majority Brexit decision could not prevent the troubled start of the post-Brexit period. Since the day Teresa May took over the government, a multilayered series of problems has stood in front of her. Boris Johnson could not prevent the third postponement. All this instability reminds us of the inadequacy and satisfaction of existing or discussed models (Stokstad, 2019).

In June 2016, nearly 51.9 percentages of UK citizens showed their choice to leave the EU, triggering the Brexit process, while $55.9 \%$ of Northern Ireland voters vote against it. The exit agreements concluded in November 2018, and then on 17 October, considerably limit the possibility of restoring a hard border between the two Ireland. Even if a no deal is obtained, in other words, an exit without an agreement from the UK for the EU is realized, it can be possible theoretically that the restoration of a physical border is going to be created. Yet, like the farmers in the country, the British fishermen have been very supportive of Brexit, even in Northern Ireland, which has nevertheless voted 56\% against leaving the EU. Irish trawlers, who will also have no access to British waters, fear that competition with European fishermen will become even more important in their own territorial waters (Tannam, 2019). Normally, fishing quotas should prevent it but it will be very tempting for European competitors without access to British waters to invest in Irish flag trawlers. Since fishing is part of European policy, the French government would not be able to put such measures in place. However, the Minister of Agriculture should receive the National Fisheries Committee in mid-February to address the issue of a potential emergency plan for the sectors most affected by Brexit (Cleg, 2017). Anyway, it is likely that a fishing agreement will be quickly between the United Kingdom and the EU in case of no deal. However, there is still no clear provision, out of fishing sector case, to evaluate the future titles on another bravery step to give, without thinking the undetermined outcomes for relations.

\section{REFERENCES}

ARNORSSON, Agust ve ZOEGA, Gylfi (2018), "On the Causes of Brexit", European Journal of Political Economy, S.55, ss.301-323.

BAAS, Timo ve BRUCKER, Herbert (2011), "EU Eastern Enlargement: The Benefits from Integration and Free Labour Movement", CESifo DICE Report, S. 9(2), ss.44-51.

BALE, Tim (2003), "Cinderella and Her Ugly Sisters: The Mainstream and Extreme Right in Europe's Bipolarising Party Systems", West European Politics, S. 26(3), ss.67-90.

BLICK, Andrew (2018), "The 2016 European Union Referendum, Consociationalism and The Territorial Constitution of The UK", Consociationalism And Power-Sharing in Europe, Palgrave Macmillan, Cham, ss.129-153.

BUDGE, Ian ve LAVER, M. J. (2016), Party Policy and Government Coalitions, Palgrave Macmillan, London.

CAMPOS, Nauro F. (2019), B for Brexit: A Survey of the Economics Academic Literature, IZA Institute of Labor Economics Press, Bonn.

CARRERA, Sergio, GUILD, Elspeth ve LUK, Ngo Chun (2016), What Does Brexit Mean for The EU's Area of Freedom, Security And Justice?, CEPS Commentary Publications, Brussels.

CHEPTEA, Angela ve HUCHET, Marilyne (2019), "Will a No-deal Brexit Disturb the EU-UK Agri-food Trade?", EuroChoices, S.18(2), ss.28-36. 
CLEGG, Nick (2017), How to Stop Brexit (and Make Britain Great Again), Random House Publishing, New York.

DOYLE, John and CONNOLLY, Eileen (2019), "The Effects of Brexit on The Good Friday Agreement And The Northern Ireland Peace Process", In: Baciu CA., Doyle J. (eds), Peace, Security and Defence Cooperation in Post-Brexit Europe, Springer, Cham, ss.79-95.

DUFF, Andrew (2016), "Borderless Debate: After Brexit, What Will Happen? Article 50: How to Leave the European Union", The Federalist Debate, S. 29(3), ss.51-55.

DUFF, Andrew (2019), "Brexit: How the Political Declaration can rescue the Withdrawal Agreement”. EPC Discussion Paper, 3 January 2019.

DUFF, Andrew (2018), "Brexit: Half In, Half out or Right Out? EPC Discussion Paper", European Policy Centre, 06.03.2018, ss.1-8, http://aei.pitt.edu/93606/1/pub_8347_brexit\%2Dhalfinhalfoutorrightout.pdf (Erişim Tarihi: 03.08.2019).

EUOBSERVER Online Newspaper (2016), "EU and Switzerland agree on free movement", Access from: https://euobserver.com/justice/136398 (Erişim Tarihi: 22.12. 2016.

EXPRESS Newspaper (2016), "REVEALED: Brexit debate has BLURRED party lines as shocking map shows a Britain DIVIDED”, :https://www.express.co.uk/news/uk/676245/REVEALED-Brexit-debate-BLURREDparty-lines-shocking-map-Britain-DIVIDED (Erişim Tarihi: 03.06. 2016).

FABBRINI, Federico (2019), "the Brexit negotiations and the May government" European Journal of Legal Studies, Special Issue, S. 1 (1), ss.1-22

FOSSUM, John Erik ve GRAVER, Hans Petter (2018), Squaring the circle on Brexit: Could the Norway model work?, Bristol University Press and Policy Press, Bristol, UK.

FROSINI, Justin Orlando (2019), "Is Brexit ripping up the unwritten constitution of the United Kingdom?", Italian Journal of Public Law, S. 11(1), ss. 1-8

GRYNBERG, Charlotte, WALTER, Stefanie ve WASSERFALLEN, Fabio (2019), "Expectations, Vote Choice, and Opinion Stability Since the 2016 Brexit Referendum.", http://www.fabiowasserfallen.ch/Website/Publications_files/grynberg_walter_wasserfallen_2019.pdf, (Erişim Tarihi: 30.01. 2019)

GUARDIAN Newspaper (2019), "Leavers are discovering the difficult truth about trade deals ed. Phillip Inman", https://www.theguardian.com/business/2019/feb/16/leavers-discovering-difficult-truth-tradedeals-brexit, (Erişim Tarihi: 16.02.2019)

KRUMM, Thomas (2019), "Reluctant Multilateralists? How Brexit Can Affect German-Turkish Relations", In Ebru Tarhan (Ed.).German-Turkish Relations Revisited, Baden-Baden, Nomos, Germany, ss. 91110.

KUCHARCZYK, Jacek ve ŁADA, Agnieszka (2017), "Poland and the EU: two-speed Europe would undermine the achievements of enlargement". flashlight europe 04/2017: Policy Brief 4/2017, http://aei.pitt.edu/86950/1/Flashlight_EZ_Poland_and_the_EU_Policy_Brief_04_2017.pdf, (Erişim Tarihi: 06.09.2019)

LYTVYNCHENKO, Ganna (2016), "Financial mechanism as a part of programme management", ProcediaSocial and Behavioral Sciences, S.230, ss. 198-203.

MATTHIJS, Matthias, PARSONS, Craig ve TOENSHOFF, Christina (2019), "Ever tighter union? Brexit, Grexit, and frustrated differentiation in the single market and Eurozone", Comparative European Politics, S.17(2), ss.209-230.

SAXI, Håkon Lunde (2019), "British-German defence and security relations after Brexit: Quo vadis, 'silent alliance'?”, The United Kingdom's Defence After Brexit, Palgrave Macmillan, Cham, ss. 127-158.

SCHEWE, Christoph ve LIPSENS, Davids (2018), "From EFTA to EC/EU and Back to EFTA? The European Economic Area (EEA) As a Possible Scenario for the UK-EU Relations After Brexit", Brexit, Springer, Cham, ss.215-235. 
SNBCHF Online Newspaper ( 2016) "Switzerland Withdraws Application To Join EU: Only 'Lunatics May Want To Join Now'”, https://snbchf.com/2016/06/durden-switzerland-withdraws-eu-application/ (Erişim Tarihi 17.06.2016).

STANSFIELD, Gareth, STOKES, Doug ve KELLY, Saul (2018), "UK Strategy in the Gulf and Middle East after American Retrenchment”, Insight Turkey,S.20(4), ss.231-248.

STOKSTAD, Erik (2019), “Brexit backer Boris Johnson stokes fears for UK scientists”, Science, S.365(6452), ss. 418

TANNAM, Etain (2019), "Brexit and The Future of UK-Irish Relations", Forthcoming in Federico Fabbrini (ed), The Law \& Politics of Brexit Volume Two: The Terms of Withdrawal, Oxford University Press, DCU Brexit Institute - Working Paper, London, UK, ss.1-16

VAHL, Marius ve GROLIMUND, Nina (2006), Integration without membership: Switzerland's bilateral agreements with the European Union. Ceps, Brussels, Belgium.

VAN DER MEI, Anne Pieter (2003), Free movement of persons within the European Community: crossborder access to public benefits, Hart Publishing, Oregon, USA

VAN KESSEL, Stijn (2015), Populist Parties across Europe. In Populist Parties in Europe: Agents of Discont, Palgrave Macmillan, London, UK.

WALTER, Stefanie (2019), "EU-27 Public Opinion about Brexit Political Behaviour Working Group: Sophia Hunger and Vicente Valentim", https://www.eui.eu/events/detail?eventid=163717, (Erişim Tarihi: 15.09.2019)

WARD, Matthew (2019), "Statistics on UK-EU trade", House of Commans Library, London, UK, file:///C:/Users/Personel_/Downloads/CBP-7851\%20(1).pdf, (Erişim Tarihi 14.08.2019). 